\title{
Determinants of rental value for residential properties: A land owner's perspective for boarding homes.
}

\author{
Nishani Wickramaarachchi \\ Department of Estate Management and Valuation, \\ Faculty of Management Studies and Commerce, \\ University of Sri Jayewardenepura. \\ nishani@sjp.ac.lk
}

\begin{abstract}
Housing is the most representative land use in any urban area. At present renting of houses instead of buying is a significant phenomenon in the housing market. The ultimate goal of owning a rental property is to make profits with little additional effort. With the absence of a guideline, land owners arbitrary evaluate the property and charges unaffordable values. Since there is no alternative, depending on the need, tenant has to accept it. On the other hand, as each piece of property is unique, it is difficult to fix a rent. This becomes worse in boarding homes. With this background the focus of this paper is on developing an index as a guideline to determine the rental value in housing market. The case study specifies the renting based on higher education institute. Hence three types of renting units such as bed, room and annex selected. The data collection was completed through a structured questionnaire. The significant of each variable is evaluated through a multiple regression model. The findings categorized into levels on the basis of the coefficient values. The results indicate that distance to main junction is the most significant variable in the three types of properties.
\end{abstract}

\section{Introduction}

Housing represents the most basic of human need and it has a profound impact on the health, welfare, and productivity of individuals (Ajilowo \& Olujimy, 2010). According to Psychologist Maslow's (1943) hierarchy of needs, it is only after we satisfy the other needs (health, clothing and shelter) that we worry about social needs.(Edward, 2007). Residential land use, among the various competing urban land uses, is the largest consumer of land in urban areas (Olayiwola, Adeleye, \& Oduwaye, 2005). Further, Cruz (2008) stated that the population and urbanization increases, demand for housing for both owner-occupancy and rental increases. However, with technological development people pushed into busy lives so that they prefer to buy already built houses. Gilderbloom and Appelbam (1990) further stated that, most of the landlords usually rented by groups such as families, professionals or students, as an alternative to buying or renting smaller spaces. Hence renting is a crucial phenomenon in any economy.

Housing is a booming industry in Sri Lanka and the research related on the subject is of vital importance (Ariyawansa 2007). In Sri Lanka people prefer to buy already built houses rather than getting built by themselves (Ariyawansa, 2009). The rental housing market is characterized as imperfect and inefficient, because the product is long-lasting, fixed on a given site, heterogeneous, and controlled by extensive governmental regulation. Since each rental housing market is confined to a given area, characteristics of a market in one area are not necessarily an accurate representation of other markets. The rental housing market is significant in Sri Lanka closer to urban areas specially where there are factories and higher educational institutes. Housing to be productive it must be provided with adequate 
infrastructure. As per Chris \& Somefun, 2007, these facilities should be available in quantity and quality on reasonable and affordable prices.

In land owners' perspective, his ultimate goal is to make a profit with little additional effort. For that better to determine the maximum amount of income can be gain from rental without having any vacancies. Most probably land lords determine the rent amounts by guessing, or decided arbitrarily or ask charges of comparable adjoining properties due to the absences of a particular guideline. Therefore, Arnott (2003) in his paper points out the benefit of rent control for the tenants as a safeguard against landlords. Sirmans and Benjamin (1991) stated that rent predictions usually modelled as a function of a bundle of housing characteristics which in terms should be safe. In tenant's perspective, they choose the dwelling that provides the best affordable combination of features. Renters tend to seek amenities, which fulfill their requirements in order to suit their cost of housing. Those amenities may be, physical features such as location, environment, neighborhood and other personal preferences or may be characteristics of the building itself such as space, age, condition, layout, kitchen facilities, etc (Chris \& Somefun, 2007). Lack of knowledge about the order of factors that determined the rental value is one of the major constraints to obtain a maximum yield.

According to McKenzie and Betts (2006), housing land use includes homes, apartments, and boarding homes. Studies on housing in Sri Lanka have not covered the guidelines on rental values for boarding homes. Hence the objective of this paper is to identify the determinants of rental value and to develop an index as a guideline for residential properties which in turn may be a supportive tool to accelerate the effective mechanism of rental market. The study is confined to the Land Owner's point of view, in a location based on the higher education institute.

\section{Literature Review Housing}

Housing is a multidimensional good differentiated into a bundle of attributes that vary in both quantity and quality (Ajilowo \& Olujimy, 2010). It is the largest single assets of most households and links the value to represent the wealth. The behaviour of house prices, therefore, influences not only business cycle dynamics, but also the performance of the financial system (Haibin, \& Tsatsaronis, K.(2004). Similar definition is given by Oram (1979) cited by Sarathchandra (2008) where it stated that housing encompasses all the auxiliary services and community facilities, that necessary for the well being of humanity. As per Oram (1979) cited in Sarathchandra (2008), housing should meet four main requirements of who occupy it;

- It should provide adequate protection from intruders

- It should be secured from the dangers of fire and structural collapse

- It should be provided under conditions which promote good health including clean and adequate water supplies and the removal of various kinds of waste (sanitation)

- It should ensure that residence enjoy adequate space and privacy

According to the above descriptions it is obviously stated that house is the fundamental need of a human and housing is the major setting for family life. It should basically provide adequate space for eating, meeting, sleeping and individual activities. Better housing means not only the provision of a physical unit with floor, walls, and roof: housing fulfills one of the most fundamental human needs of shelter.

\section{Rent}

The term "rent" has several meanings. According to Chris and Somefun (2007) rent is regarded as the monthly payment that is made to a landlord, and it is also construed to be a 
payment to the use of the building. But to the economist point of view rent is the return to the land. Most of the landlords turning to renting out properties as an investment, therefore letting market have been seen as an attractive alternative investment for these looking for a less volatile income source. Reed and Greenhalgh (2002) discussed the reasons for increasing the rental dwellings opposed to owner occupancy. A number of changes appear to have adversely affected the Rent vs. Buy decision, such as renting as a cheaper alternative, increasing exposure to other forms of non housing debt, changing attitude to investment, increased family breakdown, increase a single person household, lower fertility rate, etc

\section{Factors Affecting for Determination of Rental Value of Residential Properties}

Without standardization, each property is considered to be unique and thus is priced differently (Ruvio,2010). Because each piece of property is unique, it is often difficult to identify the appropriate variables that will explain the rental prices. According to Kim and Nelson (1996), assessing the rental value of residential properties is a complex and challenging process to both practitioners and academicians because it involves analyzing the rental property, neighborhood characteristics and market conditions. McKenzie and Betts (2006) explained these attributes include physical features such as space, age, condition and apartments. Some features can be measured by objective scale or techniques. Other amenities however are not so objective. Further, Odame (2010) clearly mentioned the a real estate asset consists of a bundle of attributes including, but not limited to location, but number of bedrooms, gross and lettable floor areas, number of storey's, type of tenure or ownership rights, plot size, quality of aesthetics and accessibility, all of which may affect its rent and price. However, Zainudeen, Senarathne, Jayasena, \& Rameezdeen (2006) see the location as a key factor from customers point of view. Chris and Somefun (2007) and Nakamura and Crone (2004) explained the attributes includes bedroom, toilet, bathroom, kitchen, open space, drainage, water supply, refuse disposal, good road net work, recreational parks, hospital and many more. Raymond (2000) further discussed that a residential property is a multidimensional commodity, characterized by durability, structural inflexibility as well as spatial fixity.

Based on the above justifications on rental values recent empirical work has investigated substantial lists of factors that have been employed to explain market rents for residential income property. These factors range from physical attributes to property management quality characteristics. In addition, the literature shows that market rent is affected by deviations of observed vacancy rates from natural vacancy rates and by such factors as rental concessions and length of residency discounts. Kim and Nelson (1995) also build a model that can provide an accurate way of assessing the rental value of residential rental property and analyzing the factors that determine market rents by using an Artificial Intelligence Technique. The model constructs Kim and Nelson (1995) in their research incorporates all variables and these independent variables are organized into four categories as follows;

RENT $=\mathrm{f}(\mathrm{BC}, \mathrm{LC}, \mathrm{TC}, \mathrm{NC})$

Where,

$\mathrm{BC}=$ Building Characteristics, $\mathrm{LC}=$ Landlord Characteristics, $\mathrm{TC}=$ TenantCharacteristics, $\mathrm{NC}$ $=$ Neighbourhood Characteristics

Building Characteristics are subdivided into building type, size of unit, amenities, and maintenance. Building type includes the number of units in the structure and age of the building. Size of rental unit includes number of rooms, number of baths and number of bed rooms. Size is the total square footage of the building. Sirmans and Benjamin (1991); Redman and Gullet (1998) all found building size to be a significant factor affecting property values.

Landlord characteristics include the investor's age, years of experience and number of properties owned. Tenant characteristics include the head of household age, race and education level. Also included are household 
income, number of children and length of residence. Neighbourhood characteristics include the tenant's option of the neighbourhood and whether or not crime is perceived to be a problem. Additional variables included are the presence of abandoned buildings and noticeable litter. Sirmans and Benjamin (1989) examine multifamily housing amenities and services and external factors affecting rent. This application is most applicable in this study, because some tenants included in the sample are sharing amenities and services with land owner.

Apart from the two most relevant rent models developed by Sirmans and Benjamin (1991) and Kim and Nelson (1995), Hardin \& Wolverto(2000), discussed a model that explains the rent should need property specific characteristics and neighborhood characteristics. A similar view is added by Oni (2009), whereas he discusses these factors may be intrinsic or extrinsic. The extrinsic factors include increase in demand for lettable space, location, condition of adjoining properties, nearness to park and leisure, local and national economic conditions. External factors are due to natural characteristics of the property which affect the city where the property is located.
With regard to the above discussion of applicable rent models related to the research, it is clear that the four categories adapted by Kim and Nelson is suitable which includes some of the factors considered by Sirmans and Benjamin(1991) in their study. Hence the study also adapted a combination of above two rent models by altering the components as compatible with the selected case study area. Marshall (1986), after conducting a survey on student rentals to determine the relationship between rent and these characteristics, find expected behavior from these variables; number of bed rooms, swimming pool, distance from campus and complex size are significant. These factors are highly applicable to the current study because most of tenants in the case study area are consisted with students of University.

\section{Analytical Framework}

According to the relevant literature in the field recent empirical studies have investigated substantial lists of factors to explain market rent for residential properties. These factors range from physical attributes to amenities, services and property management characteristics. As explained in the literature all those factors can be rearranged as appropriate to the case study area and illustrated as follows.

Table 1.1 - The Determinants of the Rental Value of the Residential Properties

\begin{tabular}{|c|c|c|}
\hline Determinants & $\begin{array}{c}\text { Independent } \\
\text { Variables }\end{array}$ & Dependent Variable \\
\hline 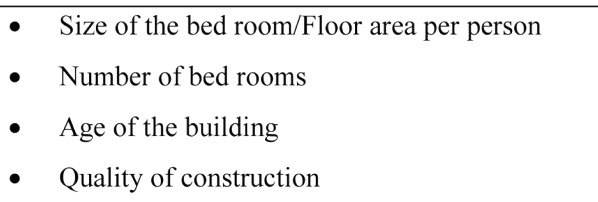 & $\begin{array}{l}\text { Physical attributes of the } \\
\text { building }\end{array}$ & \multirow{3}{*}{$\begin{array}{c}\text { Rental Value of residential } \\
\text { property }\end{array}$} \\
\hline $\begin{array}{ll}\text { - } & \text { Distance to bus route } \\
\text { - } & \text { Distance to Wijerama Junction } \\
\text { - } & \text { Distance to University of Sri Jayewardenepura }\end{array}$ & Locational factors & \\
\hline $\begin{array}{ll}\text { - } & \text { Availability of electricity } \\
\text { - } & \text { Availability of water } \\
\text { - } & \text { Neighbouhood characteristics } \\
\text { - } & \text { Characteristics of tenants } \\
\text { - } & \text { Practices of comparisons }\end{array}$ & $\begin{array}{c}\text { Amenities services and } \\
\text { other factors }\end{array}$ & \\
\hline
\end{tabular}

Source: compiled by Author, 2010 


\section{Materials and methods}

The accommodation may range from the house, one floor or room of a house, a part of a room even simply a bed according to UNESCAP/ UN-Habitat. Ministry of policy planning and implementation (1991) in Sri Lanka defined "boarding place" as a place where a habitable space, room, or rooms are made available for accommodation and related activities to persons other than family members with or without any payment being charged. Therefore this study also focused accommodation type as discussed above. Hence the definition taken is more validated and applicable regarding the current study, but only the places where payments being charged are taking into consideration.

\section{Data Collection}

For the purpose of data collection Structured Questionnaires, personal interviews and observations were used. Analyze involves Descriptive statistics, Multiple Regression Analysis and Weighted Score Technique.
Case Study area: since the study focused on renting boarding homes, Wijerama GNDivision within the Maharagama Divisional Secretariat Division selected as the case study area. This is where University of Sri Jayewardenepura is located. It is considered $500 \mathrm{~m}$ radius buffer zone from the university to collect data including routes which are consisted with highest number of rental properties.

Sampling criteria: Simple Random Sampling Technique is basically adapted for selecting rented properties in the case study area. Hundred (100) land owners are included in the sample. Following features are used as selecting criteria of sample. The sample is comprised with only three types of accommodations which are frequently rent out in the case study area as identified during the observations. Accordingly they are bed/s in a room, room $/ \mathrm{s}$ in the Owner's house and annexes.

Table 1.2-Distribution of Sample Elements in the Case Study Area

\begin{tabular}{|c|l|c|}
\hline Category & \multicolumn{1}{|c|}{ Type } & No of Elements \\
\hline A & Bed in the rooms of owner's house & 58 \\
\hline B & Room in the Owner's house & 27 \\
\hline C & Annex & 15 \\
\hline & Total & 100 \\
\hline
\end{tabular}

Source: compiled by Author, 2010

\section{Analysis of data}

\section{Sample characteristics}

Majority of land owners are in 50-60 age groups (53.7\%). 6-10 number is significant in beds which accommodate around $55 \%$ of the sample. When considering the gender composition within respondents, there is an equal distribution between male and female composition. Every accommodation is provided electricity $(100 \%)$ and water $(100 \%)$ as main requirements and security wall, regular maintenance and repairs also is in considerable level. Telephone and ceiling fans are provided for few of accommodations especially for annexes. Descriptive statistics of current charges of the selected sample are depicted as follows. 
Table1.3 - Statistics of Rental Values of Three Types of Accommodations

\begin{tabular}{|l|c|c|c|c|c|}
\hline \multicolumn{1}{|c|}{ Statistics } & Mean & Median & Std. & Minimum & Maximum \\
Type of & & & & & \\
\hline Rent (bed) p.m (Rs) & 2090.52 & 1925.00 & 569.122 & 1250.00 & 3500.00 \\
\hline Rent (room) p.m (Rs) & 4888.89 & 4916.67 & 830.122 & 3500.00 & 6500.00 \\
\hline Rent(annex) p.m (Rs) & 12600.00 & 12250.00 & 3333.809 & 7500.00 & 21000.00 \\
\hline
\end{tabular}

Source: Compiled by Author, 2010

When compare the three accommodations the deviations are higher from mean value in the rental value of annex and room rent.

\section{Analysis of the Relationship of the Factors Affecting Rental Values in Case Study Area}

Multiple regression models were used in the analysis to determine the interrelationships between each of the factors. The dependent variable was the rental value of the residential property whereas the size of the bed room/ floor area per person, distance to bus route, water availability, electricity, were taken as independent variables. The model is not only capable of handling the relationships but also it support to inform the contribution or the importance of each variable to the explanation of the variation in the dependent variable. It also allows for the prediction of value of the dependent variable.

According to the above discussed literature, the equation of multiple regression $\mathrm{Y}$ (dependent variable) on X1, X2, X3, X4,..... (Independent variables) is given as;

$\mathrm{Y}=\mathrm{a}+\mathrm{bx}=\mathrm{b} 1 \mathrm{x} 1+\mathrm{b} 2 \mathrm{x} 2+$ .+ bn $x n+e$

Where,

$\mathrm{X} 1, \mathrm{X} 2 \ldots \mathrm{Xn}=$ The independent variables

$\beta 1, \beta 2 \ldots \beta \mathrm{n}=$ Multiple regression coefficients for the independent variables(the slope of the regression line)

"e" = An error term which points to the fact that a proportion of the variance in the dependent variable

$\mathrm{Y}=$ Unexplained by the regression equation

Thus, the application of the model to the case study shows that;

$\mathrm{Y}=\mathrm{a}+\beta 1 \mathrm{FA} / \mathrm{FA} *+\beta 2 \mathrm{NB}+\beta 3 \mathrm{AB}+\beta 4 \mathrm{FL}$

$+\beta 5 \mathrm{WL}+\beta 6 \mathrm{RF}+\beta 7 \mathrm{BR}+\beta 8 \mathrm{DB}+\beta 9 \mathrm{DW}+$

$\beta 10 \mathrm{DU}+\beta 11 \mathrm{EL}+\beta 12 \mathrm{WA}+\beta 13 \mathrm{NE}+\beta 14 \mathrm{TE}$

$+\beta 15 \mathrm{PC}$

$\mathrm{Y}=\mathrm{a}+\beta 1(\mathrm{FA} 1+\mathrm{FA} 2)+\beta 2(\mathrm{NB} 1+\mathrm{NB} 2)$

$+\beta 3 \mathrm{AB}(\mathrm{AB} 1+\mathrm{AB} 2)+\beta 4(\mathrm{FL} 1+\mathrm{FL} 2)+$

$\beta 5(\mathrm{WL} 1+\mathrm{WL} 2)+\beta 6 \mathrm{RF}(\mathrm{RF} 1+\mathrm{RF} 2)+$

$\beta 7(\mathrm{BR} 1+\mathrm{BR} 2)+\beta 8(\mathrm{DB} 1+\mathrm{DB} 2)+\beta 9$

$(\mathrm{DW} 1+\mathrm{DW} 2)+\beta 10(\mathrm{DU} 1+\mathrm{DU} 2)+\beta 11$

$(\mathrm{EL} 1+\mathrm{EL} 2)+\beta 12(\mathrm{WA} 1+\mathrm{WA} 2)+\beta 13$

$(\mathrm{NE} 1+\mathrm{NE} 2)+\beta 14(\mathrm{TE} 1+\mathrm{TE} 3+\mathrm{TE} 3+\mathrm{TE} 4)+$

$\beta 15(\mathrm{PC} 1+\mathrm{PC} 2+\mathrm{PC} 3)$

Where,

Y $=$ Monthly rental value

1. Physical attributes of the building

FA $=$ Floor Area of the Bed room

Dummy variable $=1$ when $F A 1=<100 \mathrm{ft} 2(0$ otherwise), FA2- above $101 \mathrm{ft} 2$

FA* = Floor area per person

Dummy variable $=1$ when $\mathrm{FA} * 1=<25 \mathrm{ft} 2(0$ otherwise), FA*2- above $25 \mathrm{ft} 2$

$\mathrm{AB}=$ Age of the building

Dummy variable $=1$ when $\mathrm{AB} 1=<5$ years $(0$ otherwise), AB2- above 6 years

NB $=$ Number of bed rooms 
Dummy variable $=1$ when $\mathrm{NB} 1=<2(0$ otherwise), NB2- above 3

FL $=$ Type of the Floor

Dummy variable $=1$ when FL1-Tile Floor $(0$ otherwise), FL2-Cement rendered floor

\section{$W L=$ Type of the Wall}

Dummy variable $=1$ when WL1-Brick Masonry wall (0 otherwise), WL2-Cement block wall

\section{$\mathbf{R F}=$ Type of the Roof}

Dummy variable $=1$ when RF1-Roof with ceiling (0 otherwise), RF2-Roof without ceiling

\section{BR = Type of bath room}

Dummy variable $=1$ when BR1-Attached Bath $\mathrm{room} / \mathrm{s}$ (0 otherwise), BR2-Detached Bath $\mathrm{room} / \mathrm{s}$

\section{Locational factors}

\section{DB $=$ Distance to bus route}

Dummy variable $=1$ when DB1- $=<250 \mathrm{~m}(0$ otherwise), DB2- 251m-500m

\section{DW $=$ Distance to Wijerama Junction}

Dummy variable $=1$ when DW $1-=<250 \mathrm{~m}(0$ otherwise), DW2- 251m-500m

DU = Distance to University of Sri Jayewardenepura

Dummy variable $=1$ when DU1- $=<250 \mathrm{~m}(0$ otherwise), DU2- 251m-500m

\section{Amenities, services and other factors}

\section{$\mathbf{E L}=$ Availability of electricity}

Dummy variable $=1$ when EL1- Freely available (0 otherwise), EL2- Sufficiently available

\section{WA = Availability of Water}

Dummy variable $=1$ when WA1- Freely available (0 otherwise), WA2- Sufficiently available

NE $=$ Neighbourhood Characteristics

Dummy variable $=1$ when NE1 $=$ Calm and quite is (0 otherwise), NE2 = Less congestion/ privacy is

\section{TE $=$ Tenant Characteristics}

Dummy variable $=1$ when TE1 - Income level/ affordability (0 otherwise)

Dummy variable $=1$ when TE2 - Occupation (0 otherwise)

Dummy variable $=1$ when TE3 - Students $(0$ otherwise)

Dummy variable $=1$ when TE4 - Family background (0 otherwise)

\section{$\mathbf{P C}=$ Practices of comparisons}

Dummy variable $=1$ when PC1 - Charges per month including bills ( 0 otherwise)

Dummy variable $=1$ when PC2 - Special offers (0 otherwise)

Dummy variable $=1$ when PC3 - Facilities/ services provided ( 0 otherwise)

The data collected as categorical data are categorized in to indicators, and including dummy variables data input in to SPSS package for multiple regression analysis. Indicators are calculated according to the equation as follows;

No of Indicators $=K-1$

Where,

$\mathrm{K}=$ No of categories

Regression Results between Monthly Rent (Per Bed) and Factors Affecting Rental Values

According to the regression results it shows that distance to University of Sri Jayewardenepura (DU1) and floor area per person (FA*2 $>=25 \mathrm{ft} 2$ ) are the most determining variables in rental values of bed as rented unit. Next to this in order to influence, freely available water (WA1), freely available electricity (EL1), attached bath room (BR1) and neighbourhood characteristics as less congestion/privacy (NE2) are highly significant with the rental values. Other variables such as distance to bus route (DB1), distance to Wijerama junction (DW1), tiled floor (FL1), roof with ceiling (RF1), student tenant (TE3) and special offers of other comparisons (PC2) are also influencing as second order of factors for determining rental values of beds as the rented unit. 
The regressions of all variables are included to the equation as follows;

$$
\begin{aligned}
& \mathrm{Y}=\mathrm{a}+\mathrm{bx}=\mathrm{b} 1 \mathrm{x} 1+\mathrm{b} 2 \mathrm{x} 2+ \\
& \text {................................ bn } \mathrm{xn}+\mathrm{e} \\
& \mathrm{Y}=\mathrm{a}+\beta 1 \mathrm{FA}^{*}+\beta 2 \mathrm{NB}+\beta 3 \mathrm{AB}+\beta 4 \mathrm{FL}+ \\
& \beta 5 \mathrm{WL}+\beta 6 \mathrm{RF}+\beta 7 \mathrm{BR}+\beta 8 \mathrm{DB}+\beta 9 \mathrm{DW}+ \\
& \beta 10 \mathrm{DU}+\beta 11 \mathrm{EL}+\beta 12 \mathrm{WA}+\beta 13 \mathrm{NE}+\beta 14 \mathrm{TE} \\
& +\beta 15 \mathrm{PC} \\
& \mathrm{Y}=1504.586+\left[-58.024\left(\mathrm{FA}^{*} 1\right)+\right. \\
& \text { 968.511(FA*2)] }+\quad[45.350(\mathrm{NB} 1) \\
& -1117.598(\mathrm{NB} 2)]+[-117.250(\mathrm{AB} 1) \\
& \text { - 854.742(AB2)] }+[325.357(\mathrm{FL} 1)- \\
& \text { 248.102(FL2) }]+[-654.254(\mathrm{WL} 1)-854.147 \\
& (\mathrm{WL} 2)]+[621.587(\mathrm{RF} 1)-2.125(\mathrm{RF} 2)] \\
& +[711.710(\mathrm{BR} 1)-854.010(\mathrm{BR} 2)] \\
& +[421.002(\mathrm{DB} 1)-298.574(\mathrm{DB} 2)]+ \\
& \text { [325.578(DW1) - 985.124(DW2)] + [1006.080 } \\
& \text { (DU1) - 952.21(DU2)] + [722.692(EL1) } \\
& +\quad 420.214(\mathrm{EL} 2)]+[801.533(\mathrm{WA} 1) \\
& +472.258(\mathrm{WA} 2)]+[592.278(\mathrm{NE} 1)+ \\
& \text { 608.124(NE2)]-[12.578(TE1) - 924.897(TE2) } \\
& \text { +158.247(TE3)-598.578(TE4)]-[21.487(PC1) }
\end{aligned}
$$

$$
\begin{aligned}
& +254.257(\mathrm{PC} 2)+129.215(\mathrm{PC} 3)] \\
& \mathrm{R}^{2}=0.753 \text { Adj. } \mathrm{R}^{2}=0.646 \quad \mathrm{~N}=58
\end{aligned}
$$

The model, R2 (0.753) shows that about $75.3 \%$ of the variation in rental value are jointly represented by the variables.

\section{Step Wise Regression Analysis between Monthly Rent Per Bed and Factors Affecting Rental Values}

Further, the step wise regression run and results indicates only two variables are mostly influencing on rental values of bed as the rented unit. Accordingly, the most crucial is distance to university of Sri Jayewardenepura $(=<250$ $m$ ) with a coefficient of 1258.149 and secondly floor area per person (above $25 \mathrm{ft} 2$ ) with a coefficient of 1069.270. These two variables are accounted $\mathrm{R} 2$ value as 0.829 and it indicates that about $82.9 \%$ contributed for determination of rental values in bed as the rented unit.

Table 1.4 - Step Wise Regression Results between Monthly Rent (Per Bed) and Factors Affecting Rental

\begin{tabular}{|c|c|c|c|c|c|}
\hline Code & Variables & Determinants & $\begin{array}{c}\text { Regression } \\
\text { coefficient }\end{array}$ & $\begin{array}{c}\text { Beta } \\
\text { coefficient }\end{array}$ & Significance \\
\hline Constant & & 1924.006 & & 0.000 \\
\hline FA $^{*}$ & $\begin{array}{c}\text { Distance to university of } \\
\text { Sri Jayewardenepura }\end{array}$ & DU1 - =<250 m & 1258.149 & 1.325 & 0.000 \\
\hline
\end{tabular}

Source: Compiled by Author 2010

$\mathrm{Y}=1924.006+1258.149(\mathrm{DU} 1)+1069.270$ $\left(\mathrm{FA}^{*} 1\right)$

$\mathrm{R} 2-0.829$

Adj. $\mathrm{R} 2=0.817$

\section{Analysis of the Relationship of the Factors Affecting Rental Values Of a Room as the Rented Unit}

Estimated results shows that floor area of the bed room $(\mathrm{FA} 1>=100 \mathrm{ft} 2)$ and distance to university of Sri Jayewardenepura (DU1<= $250 \mathrm{~m}$ ) are the most determining variables in rental values of a room as rented unit. Then, freely available water (WA1), freely available electricity (EL1), attached bathroom (BR1) and tiled floor (FL1), neighbourhood characteristics such as less congestion/privacy (NE2), roof with ceiling (RF1), are highly significant with the rental values. Other variables such as distance to bus route (DB1 $<=250 \mathrm{~m})$, distance to Wijerama junction (DW1 $=<250 \mathrm{~m}$ ), number of bed rooms (NB2=above 3 ), student tenant (TE3) and special offers of other comparisons (PC2) are also influencing as second order of factors for determining rental values of room as the rented unit.

The regressions of all variables are included to the equation as follows; 


$\mathrm{Y}=\mathrm{a}+\mathrm{bx}=\mathrm{b} 1 \mathrm{x} 1+\mathrm{b} 2 \mathrm{x} 2+$
$\ldots \ldots \ldots \ldots \ldots \ldots \ldots \ldots \ldots \ldots \ldots \ldots+\mathrm{bn} x+\mathrm{e}$
$\mathrm{Y}=\mathrm{a}+\beta 1 \mathrm{FA}+\beta 2 \mathrm{NB}+\beta 3 \mathrm{AB}+\beta 4 \mathrm{FL}+\beta 5 \mathrm{WL}$
$+\beta 6 \mathrm{RF}+\beta 7 \mathrm{BR}+\beta 8 \mathrm{DB}+\beta 9 \mathrm{DW}+\beta 10 \mathrm{DU}+$
$\beta 11 \mathrm{EL}+\beta 12 \mathrm{WA}+\beta 13 \mathrm{NE}+\beta 14 \mathrm{TE}+\beta 15 \mathrm{PC}$
$\mathrm{Y}=5400.215+[89.120(\mathrm{FA} 1)+2624.258(\mathrm{FA} 2)]$
$+[127.254(\mathrm{NB} 1)-587.020(\mathrm{NB} 2)]+[$
$-1187.277(\mathrm{AB} 1)-2854.742 \quad(\mathrm{AB} 2)]+$
$[848.240(\mathrm{FL} 1)-348.102(\mathrm{FL} 2)]+[-1654.254$
$(\mathrm{WL} 1)-2854.147 \quad(\mathrm{WL} 2)]+[547.120$
$(\mathrm{RF} 1)-102.358(\mathrm{RF} 2)]+[989.245(\mathrm{BR} 1)$
$-1754.147(\mathrm{BR} 2)]+[325.786(\mathrm{DB} 1)-$
$124.21(\mathrm{DB} 2)]+[257.654(\mathrm{DW} 1)-125.501$
$(\mathrm{DW} 2)]+[2457.25(\mathrm{DU} 1)-1254.214(\mathrm{DU} 2)]$
$+[1557.247(\mathrm{EL} 1)+254.214 \quad(\mathrm{EL} 2)]+$
$[1090.578(\mathrm{WA} 1)+214.958(\mathrm{WA} 2)]+[698.785$
$(\mathrm{NE} 1)+808.124(\mathrm{NE} 2)]+[-232.751(\mathrm{TE} 1)$
$+125.369(\mathrm{TE} 2)+178.247(\mathrm{TE} 3)-698.578$
$(\mathrm{TE} 4)]+[-54.210(\mathrm{PC} 1)+113.014(\mathrm{PC} 2)$
$+109.247(\mathrm{PC} 3)]$

$\mathrm{R} 2=0.815 \quad$ Adj. $\mathrm{R} 2=0.784 \mathrm{~N}=2$

The model R2 (0.815) shows that about $81.5 \%$ of the variation in rental value are mutually accounted by the variables. According to above calculated coefficients in each variable, Floor area of the bed room (above $101 \mathrm{ft} 2$ ) and distance to university of Sri Jayewardenepura $(=<250 \mathrm{~m})$ depict the highest and these two variables are very much significant with the rental value of the room in the case study area.

\section{Step Wise Regression Analysis between Monthly Rent Per Room and Factors Affecting Rental Values}

According to the result of the step wise regression analysis two of the determinants are very crucial for the determination of rental value. Accordingly, the most crucial is floor area of the bed room (above $101 \mathrm{ft} 2$ ) with the regression coefficient of 3120.020 and secondly distance to university of Sri Jayewardenepura $(=<250 \mathrm{~m})$ with a regression coefficient of 1258.149 . These two variables are together accounted R2 value as 0.856 and it indicates that about $85.6 \%$ of magnitude, these two significant factors are contributed for determination of rental values in rooms as the rented unit in the study area.

Table 1.5 - Step Wise Regression Results between Monthly Rent (Per Room) and Factors Affecting Rental Values

\begin{tabular}{|c|c|c|c|c|c|}
\hline Code & Variables & Determinants & $\begin{array}{c}\text { Regression } \\
\text { coefficient }\end{array}$ & $\begin{array}{c}\text { Beta } \\
\text { coefficient }\end{array}$ & Significance \\
\hline FA & Constant & & 4972.974 & & 0.000 \\
\hline DU & $\begin{array}{c}\text { Distance to University of Sri } \\
\text { Jayewardenepura }\end{array}$ & DU1-<=250 m & 2782.873 & 1.006 & 0.000 \\
\hline
\end{tabular}

$\mathrm{Y}=4972.974+3120.020(\mathrm{FA} 2)+2782.873(\mathrm{DU} 1)$

R2 - $0.856 \quad$ Adj. R2 $=0.849$

Analysis of the Relationship of the Factors Affecting Rental Values of an Annex

\section{Regression Results (Estimates) Between Monthly Rent (Per Annex) and Factors Affecting Rental Values}

As regression estimates indicates, with regard to the significance level of variables, floor area of the bed room $(\mathrm{FA} 2=$ above $101 \mathrm{ft} 2)$, no of bed rooms (NB2=above 3 ), availability of water (WA1=freely available), neighbourhood characteristics ( $\mathrm{NE} 1=$ calm and quite is), availability of electricity (EL1=freely available), type of bath room (attached bath room), distance to bus route (DB1=<250 m), distance to wijerama junction $(\mathrm{DW} 1=<250 \mathrm{~m})$, type of floor $(\mathrm{FL} 1=$ tiled floor), type of roof $(\mathrm{RF} 1=$ roof with ceiling) and distance to university(DU1 $=<250 \mathrm{~m})$. 
The variables age of the building, type of wall are not highly significant relationships with rental value of an annex in the case study area.

The regressions of all variables are included to the equation as follows;

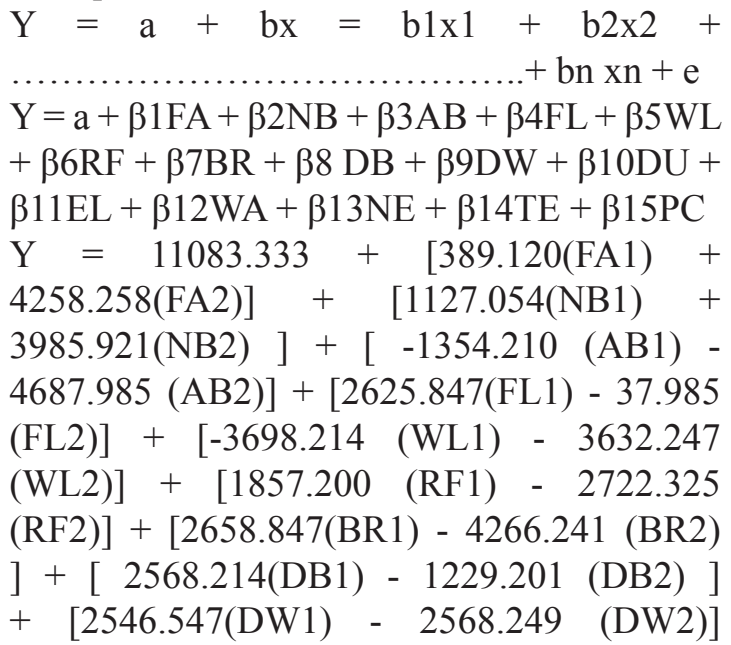

$$
\begin{aligned}
& +[1825.987 \text { (DU1) }-2515.002(\mathrm{DU} 2)] \\
& +[2814.254(\mathrm{EL} 1)+725.363 \quad(\mathrm{EL} 2)]+ \\
& {[3834.875(\mathrm{WA} 1)-1568.249 \quad(\mathrm{WA} 2)+} \\
& {[3824.984(\mathrm{NE} 1)+998.241(\mathrm{NE} 2)]+[1005.811} \\
& (\mathrm{TE} 1)-98.354(\mathrm{TE} 2)+658.414(\mathrm{TE} 3)-36.274 \\
& (\mathrm{TE} 4)]+[258.211(\mathrm{PC} 1)-369.714(\mathrm{PC} 2)- \\
& 34.280(\mathrm{PC} 3)] \\
& \mathrm{R} 2=0.791 \quad \text { Adj. R2 }=0.763 \mathrm{~N}=17
\end{aligned}
$$

According to the variables fitted in to the regression model it is represented that R2 (0.791) shows that about $79.1 \%$ of the variation in rental value are mutually accounted for by the variables considered in this analysis. The standard coefficients value of the independent variable depicts the degree of each variable influence to the rental value of an annex in the area. Hence, according to the analysis, size of the bed room (above $101 \mathrm{ft} 2$ ) and no of bed rooms (above 3 ) are the most significant. Further step wise regression results are shown as below.

Table1.6 Step Wise Regression Results between Monthly Rent (Per Annex) and Factors Affecting Rental Values

\begin{tabular}{|c|c|l|c|c|c|}
\hline Code & \multicolumn{1}{|c|}{ Variables } & \multicolumn{1}{|c|}{ Determinants } & $\begin{array}{c}\text { Regression } \\
\text { coefficient }\end{array}$ & $\begin{array}{c}\text { Beta } \\
\text { coefficient }\end{array}$ & Significance \\
\hline & Constant & & 11954.443 & & 0.000 \\
\hline FA & $\begin{array}{c}\text { Floor area of the bed } \\
\text { room }\end{array}$ & FA2 - above 101 $\mathrm{ft}^{2}$ & 4985.026 & 3.954 & 0.000 \\
\hline NB & No of bed rooms & NB2 - above 3 & 4169.255 & 3.009 & 0.000 \\
\hline
\end{tabular}

Source: Compiled by Author, 2010

$\mathrm{Y}=11954.443+4985.026(\mathrm{FA} 2)+4169.255$

(NB2)

$\mathrm{R} 2-0.844 \quad$ Adj. $\mathrm{R} 2=0.836$

According to the result of the step wise regression two of the determinants are very crucial for the determination of rental value. Floor area of the bed room (above $101 \mathrm{ft} 2$ ) with the regression coefficient of 4985.443 and secondly number of bed rooms (above 3 ) with a regression coefficient of 4169.255. These two variables are together represents R2 value as 0.856 and it pointed out that about $84.4 \%$ of a magnitude, are contributing to the rental values in an annex.

\section{Conclusion}

According to the regression results it shows that below $250 \mathrm{~m}$ distance to University of Sri Jayewardenepura and above $25 \mathrm{ft} 2$ floor area per person are the most determining variables in rental values of bed as rented unit. As second order factors in order to influence, freely available water, freely available electricity, attached bath room and neighbourhoods characteristics as less congestion/privacy are highly significant with the rental values. Other variables such as below $250 \mathrm{~m}$ distance to bus route below $250 \mathrm{~m}$ distance to Wijerama junction, tiled floor, roof with ceiling, student 
tenant and special offers of other comparisons are also influencing as third order of factors affecting for determining rental values of beds as the rented unit.

After identification of most influencing variables in respect to Beta coefficient values, model 1 specified that the most determining factors which are highly significant with the rental values of the beds as rented unit.

\section{Model 1 - Determination of Rental Value per Bed in Owner's House}

Where, $\mathrm{Y}=$ Monthly Rental Value per Bed, $\mathrm{Y}=\mathrm{f}[(\mathrm{DU} 1)+(\mathrm{FA} * 2)+(\mathrm{FL} 1)+(\mathrm{RF} 1)+$ $(\mathrm{BR} 1)+(\mathrm{DB} 1)+(\mathrm{DW} 1)+(\mathrm{EL} 1)+(\mathrm{WA} 1)+$ $(\mathrm{NE} 2)+(\mathrm{TE} 3)+(\mathrm{PC} 2)]$

Room rent estimates proved that above $101 \mathrm{ft} 2$ floor area of the bed room and below $250 \mathrm{~m}$ distance to university of Sri Jayewardenepura is the most determining variables in rental values of a room as rented unit. Second order determinants are, freely available water, freely available electricity, attached bathroom and tiled floor, neighbourhood characteristics as less congestion/privacy, roof with ceiling. Other factors such as below $250 \mathrm{~m}$ distance to bus route, below $250 \mathrm{~m}$ distance to Wijerama junction, above three of bed rooms, student tenant and special offers are also influencing as third order of factors for determining rental values of room as the rented unit.

\section{Model 2 - Determination of rental value per room in owner's house}

Where, $\mathrm{Y}=$ Monthly Rental Value per Room $\mathrm{Y}=\mathrm{f}[(\mathrm{DU} 1)+(\mathrm{FA} 2)+(\mathrm{NB} 2)+(\mathrm{FL} 1)+(\mathrm{RF} 1)$ $+(\mathrm{BR} 1)+(\mathrm{DB} 1)+(\mathrm{DW} 1)+(\mathrm{EL} 1)+(\mathrm{WA} 1)+$ $(\mathrm{NE} 2)+(\mathrm{TE} 3)+(\mathrm{PC} 2)]$

Further, the regression estimates indicates in annex rent, with regard to the significance level of variables, above $101 \mathrm{ft} 2$ floor area of bed room, above three bed rooms in an annex are the highly significant factors for influencing rental values of annexes. As second or- der influencing factors freely available water, calm and quiet neighbourhood, freely available electricity, attached bath room, below 250 $\mathrm{m}$ distance to bus route, below $250 \mathrm{~m}$ distance to wijerama junction, tiled floor, roof with ceiling and below $250 \mathrm{~m}$ distance to university are affect rental values and thirdly, student tenant and charges of the comparisons charges per month are significant with the rental values of annex. After identification of most influencing variables in respect to magnitude of Beta coefficient values, model 3 specified that the most determining factors which are highly significant with the rental values of an annex as rented unit.

\section{Model 3 - Determination of Rental Value of an Annex}

Where, $\mathrm{Y}=$ Monthly Rental Value per Annex $\mathrm{Y}$ $=\mathrm{f}[(\mathrm{FA} 2)+(\mathrm{NB} 1)+(\mathrm{FL} 1)+(\mathrm{RF} 1)+(\mathrm{BR} 1)$ $+(\mathrm{DW} 1)+(\mathrm{DU} 1)+(\mathrm{EL} 1)+(\mathrm{WA} 1)+(\mathrm{NE} 1)+$ $(\mathrm{TE} 3)+(\mathrm{PC} 1)]$

The outcomes of the results which indicated by the above models developed on the basis of coefficient values are in par with the results identified in the relevant literature. This in turn basically can be used as a guideline for land owners to decide their rent in more rational approach in beds, rooms or annex. It may make obvious them to identify the existing and future potentials of their properties. Ultimately, it helps to obtain maximum yield from their properties and it may assist to strengthen their living standards as well.

Conversely, tenant can find the accommodations which realize the requirements in respect to tenant are needs under the reasonable rental payment. On the other way if the tenant can save money through an affordable rent on housing, the rest can invest for the betterment of the country. In a more broad view, the research findings can serve as a guideline to the particular area for determination of rent and it may try on separate areas where there is a possibility to save the land on converting into residential on haphazard basis. 


\section{References}

Ajilowo, J., \& Olujimi, B. (2010). Analysis of the relationships of infrastructural facilities in the determination of rental values of residential properties in Akure, Nigeria, Arts and Social Sciences Journal, Volume 2010(10), 1-11.

Ariyawansa, R. G. (2007). An empirical study on consumer behavior in housing market in Colombo, Built - Environment-Sri Lanka, 8(1), 11-19.

Ariyawansa, R. G. (2009). Housing Market: A Review of purchase Decision of Potential Buyers, Author Publication, Colombo.

Arnott, R. (2003), Tenancy rent control, Swedish Economic Policy Review, 10, 91-121.

Chris, A. O., \& Somefun, A. O. (2007).The effects of facilities provision on rental values of residential properties in Ikeja: Logos State, Journal of Land Use and Development Studies, 3, 61-67.

Cruz, P. C. (2008). Transaction cost and housing affordability in Asia, International Real Estate Review,11(1), 128-150.

Edwards, M. E. (2007).Regional urban economics and economic development: Theory and methods, Auerbach Publications, New York.

Gilderbloom, J. I., \& Appelbam, R. P. (1990). Toward sociology of rent-Are rental housing market competitive, Social Problems,34 (3), 261-27.

Haibin, Z., \& Tsatsaronis, K.(2004). What drives housing price dynamics: Cross-country Evidence, BIS Quarterly Review, 64-78.

Hardin, W. G., \& Wolverton, M.(2000), Micro -market determinants of neighborhood center rental rates, Journal of Real Estate Research, 20,(3), 299-322.
Kim, K. S., \& Nelson, W. A. (1996).Assessing the Rental Value of Residential Properties; an Abductive Learning Networks Approach, Journal of Real Estate Research, 12, 63-76.

Marshall D W (1990), "The Influence of Property Market Characteristics on Rents, Working Paper, Miami University,Ohio.

Ministry of Policy Planning and Implementation-Human Settlement Division (1991), Formulation for building guidelines for boarding houses, Vol. 2, Sri Lanka.

Mckenzie, J. D. \& Betts, R. M. (2006), Essentials of Real Estate Economics, (5th ed) USA, Delmar Cengage.

Nakamura, L. I. \& Crone, T. M. (2004). Hedonic Estimates of the Cost of Housing Services: Rental and Owner-Occupied Units, Working paper, Federal Reserve Bank of Philadelphia 04-22.

Odame, W. K. A.(2010). Residential market development in Sub-Saharan Africa, International Journal of Housing Markets and Analysis, 3(4), 308-326.

Olawande, O. A. (2009). Arterial road network and commercial property values in Ikeja, Nigeria, $\mathrm{PhD}$ thesis submitted to university of Ota, Nigeria.

Olayiwola, L.M., Adeleye, O. A., \& Oduwaye, A. O. (2005). Correlates of land value determinants in Lagos metropolis, Nigeria, Journal of Human Ecology, 17(3), 183-189.

O'Sullivan, A.(1999). Urban Economics (5th ed.). New York: McGraw-Hill/Irwin.

Raymond, J.S. (2000), Homeownership and housing finance policy in the former Soviet Bloc, 1-219. 
Redman, A. L., \& Gullett, N. S.(1998), An empirical study of the impact of foreign ownership on the values of U.S. commercial properties, Journal Of Financial And Strategic Decisions, 11,(1), 53-60

Reed, R., \& Greenhaigh, E. (2002). The Changing Nature of the Rent vs. Buy Decision and Implications for the Housing Market, Asres/AREUEA Joint International Conference, Seoul, Korea, 4-6 July 2002

Ruivo, R. (2010). Determinants of rental rates in major cities in the United States, Bryant economic research paper,3(7), 1-14
Sarachchandra, C. A. (2008). Housing development finance in Sri Lanka, Colombo Sirmans, G. S., \& Benjamin, J. D. (1989). Determining Apartment Rent: The Value of Amenities, Services and External Factors, Journal of Real Estate Research, 4(1)

Sirmans, G. S., \& Benjamin, J. D. (1991). Determinants of Market Rent, Journal of Real Estate Research, 6, 357-378.

Zainudeen, N. Senarathne, S. Jayasena, S. \& Rameezdeen, R.(2006). Horizontal housing property market, Built- Environment-,Sri Lanka, 7(1), 16-22. 